E-JURNAL EKONOMI DAN BISNIS UNIVERSITAS UDAYANA
Available online at https://ojs.unud.ac.id/index.php/EEB/index
Vol. 10 No. 10, October 2021, pages: $911-920$
e-ISSN: 2337-3067

\title{
BRANDING DIGITAL LABUAN BAJO DALAM MENARIK FREE INDEPENDENT TRAVELER CINA
}

\section{Ni'matun Nasim ${ }^{1}$ A.A. Putu Agung Suryawan Wiranatha' ${ }^{2}$ Gusti Ayu Oka Suryawardani ${ }^{3}$}

\begin{tabular}{l} 
Article history: \\
\hline Submitted: 7 Juli 2021 \\
Revised: 24 Juli 2021 \\
Accepted: 17 Agustus 2021 \\
\hline Keywords: \\
Digital Marketing; \\
Labuan Bajo; \\
FIT; \\
China;
\end{tabular}

\section{Kata Kunci:}

Pemasaran Digital;

Labuan Bajo;

FIT;

Cina;

\section{Koresponding:}

Pusat Unggulan Pariwisata

Universitas Udayana ${ }^{3}$

Email:

gungdani@gmail.com ${ }^{3}$

Abstract
Free Independent Traveler (FIT) is the majority market of Labuan
Bajo, including Chinese FIT. The main characteristic of this market is their
dependency on the internet, therefore build up the destination image
through digital marketing is very essential. The objective of this study were
to identify the potential of Labuan Bajo as Indonesia super priority
destination, to analyze main atraction of Labuan Bajo for Chinese FIT
market, and to develop Labuan Bajo digital branding stategy for Chinese
FIT. This research used qualitative descriptive by implementing data
through literature review, observation, interview, and social listening.
Data was analyzed by using qualitative descriptive analysis and SWOT
analysis. The result showed that Pink Beach, Padar Island, komodo, and
live on board could be used as the brand icon of Labuan Bajo in Chinese
FIT marketing digital system. Therefore, Labuan Bajo should choose the
right digital platform, start using Mandarin language, and build up
partnership with Chinese key opinion leader (KOL) in each content to
ensure Labuan Bajo promises well receipt by Chinese FIT online
community.

Abstrak

Free Independent Traveler (FIT) merupakan mayoritas pasar terbesar di Labuan Bajo, termasuk wisatawan FIT asal Cina. Karakteristik utama jenis wisatawan ini adalah ketergantungannya terhadap internet, sehingga sangat penting bagi suatu destinasi untuk memanfaatkan pemasaran digital dalam pembangunan citra destinasi. Tujuan dari penelitian ini antara lain adalah untuk mengidentifikasi potensi Labuan Bajo sebagai destinasi super prioritas di Indonesia, menganalisis daya tarik utama Labuan Bajo bagi wisatawan FIT Cina, dan mengembangkaan strategi branding digital Labuan Bajo dalam konteks wisatawan FIT Cina. Penelitian ini menggunakan pendekatan kualitatif deskriptif dengan pengambilan data melalui kajian pustaka, observasi, wawancara, dan social listening. Data yang diperoleh dianalisis dengan metode analisis kualitatif deskriptif dan analisis SWOT. Hasil penelitian menunjukkan bahwa Pink Beach, Pulau Padar, komodo, dan kegiatan live on board dapat dijadikan sebagai representasi brand Labuan Bajo dalam sistem pemasaran digital Cina. Oleh karena itu, Labuan Bajo disarankan untuk memilih platform digital Cina yang tepat, menggunakan bahasa Mandarin, dan bekerja sama dengan key opinion leader (KOL) Cina di setiap unggahan konten demi memastikan janji (promise) Labuan Bajo tersampaikan dengan baik di komunitas daring wisatawan FIT Cina.

Prodi Magister Pariwisata Universitas Udayana ${ }^{1}$

Email: nimatunasim@gmail.com ${ }^{1}$

Pusat Unggulan Pariwisata Universitas Udayana ${ }^{2}$

Email: balitruly@yahoo.com² 


\section{PENDAHULUAN}

Branding merupakan salah satu komponen penting dalam strategi pemasaran. Kotler \& Gertner (2004) juga menegaskan bahwa performa branding destinasi dapat berpengaruh positif terhadap angka wisatawan yang berkunjung ke satu destinasi. Dengan adanya internet, proses branding yang dulu dilakukan secara offline, kini juga bisa dilakukan dengan cara online, seperti memanfaatkan berbagai platform digital seperti aplikasi digital dan media sosial. Wisatawan mandiri atau yang sering disebut sebagai free independent traveler (FIT) merupakan pasar wisatawan yang sangat bergantung pada informasi destinasi yang terdapat dalam internet. Salah satu destinasi di Indonesia yang memiliki mayoritas pasar wisatawan FIT adalah Labuan Bajo (Rudiyanto et al., 2021). Eksistensi Labuan Bajo sebagai destinasi wisata semakin populer di kelompok wisatawan FIT sejak tahun 2011, yaitu ketika Labuan Bajo masuk dalam daftar finalis Tujuh Keajaiban Dunia Baru dan puncaknya adalah ketika festival Sailing Komodo dilaksanakan pada tahun 2013 (Kodir et al., 2020).

Labuan Bajo telah ditetapkan sebagai destinasi super prioritas oleh pemerintah pusat sejak tahun 2019. Labuan Bajo menawarkan konsep pariwisata minat khusus dengan daya tarik utama adalah keindahan ekosistem alam kepulauan lengkap dengan komodo sebagai fauna endemik yang hanya ada di Indonesia. Selain itu, budaya Labuan Bajo juga mulai dikembangkan oleh pihak destinasi untuk memperkuat potensi produk pariwisata Labuan Bajo. Beberapa atraksi utama yang ditawarkan oleh Labuan Bajo telah berhasil menciptakan pertumbuhan jumlah wisatawan dari tahun ke tahun. Berdasarkan data Bandar Udara Komodo (2019), total kedatangan wisatawan mancanegara adalah 137.740 orang. Apabila ditinjau dari asal negaranya, wisatawan yang banyak berkunjung ke Labuan Bajo pada tahun 2019 adalah wisatawan asal Perancis, Cina, Inggris, dan Amerika Serikat.

Berkenaan dengan wisatawan Cina, Direktur Pemasaran Badan Pelaksana Otorita Labuan Bajo Flores (BPO LBF) menyatakan bahwa wisatawan Cina merupakan pasar potensial bagi perkembangan Labuan Bajo ke depan. Hal ini terlihat dari konsistensi jumlah kedatangan wisatawan Cina selama tahun 2019 yang cenderung meningkat. Lebih lanjut Direktur Pemasaran BPO LBF (2020) juga menekankan bahwa kendala utama dalam mengelola pasar wisatawan FIT Cina adalah perbedaan bahasa dan sistem digital yang digunakan oleh negara Cina. Oleh karena itu, tidak mengherankan apabila nama Labuan Bajo belum sebesar Bali dalam hal branding di sistem digital Cina. Mengacu pada keterbatasan Labuan Bajo dalam hal pemasaran brand di sistem digital Cina, maka penelitian ini berusaha mencari model strategi branding Labuan Bajo dalam sistem digital Cina, sehingga dapat memperkuat integritas brand Labuan Bajo di pasar wisatawan FIT Cina.

Kajian ini menggunakan beberapa teori untuk membantu alur analisis dalam mencapai tiga tujuan penelitian, yaitu 1) mengidentifikasi potensi Labuan Bajo sebagai destinasi super prioritas; 2) menganalisis daya tarik utama Labuan Bajo bagi wisatawan Cina; dan 3) menyusun strategi branding digital Labuan Bajo untuk menarik wisatawan FIT Cina. Dalam mengidentifikasi potensi Labuan Bajo sebagai destinasi super prioritas, teori $4 \mathrm{~A}$ dari Cooper untuk diimplementasikan pada empat komponen utama Labuan Bajo sebagai destinasi, yaitu attraction, accessibility, amenity, dan ancillary (Suwena et al., 2010). Selain itu, kajian ini juga menggunakan tiga teori untuk menganalisis pasar wisatawan FIT Cina. Ketiga teori tersebut adalah teori citra destinasi pariwisata yang fokus pada bagaimana branding destinasi terbentuk di benak wisatawan (Pike, 2008), teori customer path 5A (Kotler et al., 2017) yang membahas setiap fase perjalanan konsumen dalam melihat suatu brand, mulai dari aware (mengenal eksistensi brand) hingga advocate (mempromosikan brand), dan teori uses and gratification yang fokus pada preferensi konsumen dalam memilih media atau platform ketika mencari informasi mengenai suatu brand (Son, 2015).

Setelah memperoleh data terkait mengenai Labuan Bajo dan pasar wisatawan FIT Cina, maka langkah selanjutnya adalah menggunakan pendekatan strategi manajemen (Evans, 2015), strategi 
manajemen brand (Keller et al., 2015), model segitiga strategi-taktik-nilai (Kotler et al., 2004; Suryawardani et al., 2021), dan integrasi pemasaran tradisional dan digital (Kotler et al., 2017) untuk mengaitkan antara teori dan hasil temuan lapangan. Hasil dari kombinasi analisis dengan menggunakan semua teori dan pendekatan tersebut akan dipaparkan dan dikeluarkan menjadi sebuah strategi branding digital Labuan Bajo dalam menarik wisatawan FIT Cina.

\section{METODE PENELITIAN}

Data yang diperoleh dalam kajian ini diperoleh melalui proses observasi lapangan di Labuan Bajo pada bulan November 2020, studi dokumen, dan social listening 137 tulisan perjalanan wisatawan FIT Cina ke Labuan Bajo dalam platform digital Mafengwo dan wawancara terstruktur dengan pihak destinasi Labuan Bajo (Direktur Utama BPO LBF, Direktur Pemasaran BPO LBF, Kepala Dinas Pariwisata dan Kebudayaan Manggarai Barat, dua perwakilan agen perjalanan, dua perwakilan ahli pemasaran digital, perwakilan akademisi, dan perwakilan pemandu wisata berbahasa Mandarin) dan pihak pasar wisatawan FIT Cina (10 warga negara Cina yang tinggal di kota tier 1 dan emerging 1 Cina). Teknik analisis kajian ini menggunakan pendekatan deskriptif kualitatif, identifikasi analisis internal dan eksternal dan teknik analisis SWOT untuk merumuskan strategi produk Labuan Bajo yang telah disesuaikan dengan preferensi pasar wisatawan FIT Cina.

\section{HASIL DAN PEMBAHASAN}

Dalam menganalisis potensi Labuan Bajo, teknik analisis yang digunakan adalah analisis internal dan eksternal. Analisis internal akan menggunakan bantuan teori 4A untuk melihat sisi destinasi, sedangkan analisis eksternal akan menggunakan teori citra destinasi pariwisata, customer path 5A, dan teori uses \& gratification. Berdasarkan hasil analisis lapangan, daya tarik alam dan budaya Labuan Bajo sangat berpotensi untuk dikembangkan menjadi destinasi super prioritas Indonesia dan menarik lebih banyak wisatawan FIT Cina untuk berkunjung. Dari hasi social listening, mayoritas wisatawan FIT Cina sangat menyukai kegiatan bahari yang ada di sekitar Taman Nasional Komodo (TNK), seperti live on board, menyelam, snorkeling, dan jelajah pulau. Hal lain yang disukai oleh wisatawan FIT Cina dari Labuan Bajo adalah keramahan masyarakat lokal dan hasil olahan makanan laut yang ada di pasar dermaga Labuan Bajo. Dengan kata lain, dari salah satu komponen 4A, komponen atraksi Labuan Bajo memiliki daya tarik yang paling kuat untuk menarik wisatawan FIT Cina.

Komponen 4A yang lain seperti aksesibilitas, amenitas, dan kelembagaan masih dalam proses berkembang. Dari segi aksesibilitas, Labuan Bajo sedang melakukan pembangunan beberapa proyek seperti perluasan bandara dan pemberian hak pengelolaaan bandara ke Changi Airport setelah proses lelang, penataan pelabuhan dan dermaga Labuan Bajo, hingga pembanguan akses jalan raya di jalurjalur utama Labuan Bajo (Buletin BPIW Kementerian PUPR, 2020). Semua proses pembangunan tersebut ditargetkan akan selesai di tahun 2022 untuk menjadi tuan rumah pertemuan ASEAN Summit dan Pertemuan G-20 pada tahun 2023. Dari segi amenitas, Labuan Bajo masih memiliki banyak hal yang perlu diperbaiki, seperti jumlah hotel bintang lima masih sangat terbatas, jaringan telekomunikasi belum stabil, sistem pengelolaan sampah belum optimal, standarisasi kualitas pelayanan kuliner belum terbentuk, hingga transparansi harga kapal wisata yang masih dikeluhkan oleh wisatawan (BPO LBF, 2021). Dari segi kelembagaan, Labuan Bajo juga masih perlu melakukan serangkaian program peningkatan kualitas dikarenakan kualitas SDM Labuan Bajo yang belum merata (Direktur Utama BPO LBF, 2021); Himpunan Pramuwisata Indonesia (HPI) Labuan Bajo belum siap dalam 
menghadapi wisatawan FIT Cina (Vincent, 2021); hingga peran asosiasi pariwisata yang belum maksimal dalam proses percepatan pembangunan destinasi super prioritas (Direktur Utama BPO LBF, 2021). Dari semua pembahasan komponen 4A dalam kajian ini, maka dapat disimpulkan bahwa komponen terkuat Labuan Bajo adalah daya tarik alam, terutama jika dilihat dari segi keunikan hewan komodo yang memang hanya ada di Taman Nasional Komodo, tetapi jika dilihat dari komponen yang lain, seperti atraksi budaya, aksesibilitas, amenitas, dan kelembagaan, Labuan Bajo masih dalam tahap berkembang, sehingga banyak sekali program pembangunan yang dilakukan oleh pemerintah pusat dan daerah untuk menyongsong target Labuan Bajo menjadi salah satu destinasi super prioritas di Indonesia.

Sebelum membahas mengenai daya tarik utama Labuan Bajo bagi wisatawan FIT Cina, maka terlebih dahulu akan dipaparkan secara umum mengenai karakteristik wisatawan FIT Cina yang telah berkunjung ke Labuan Bajo, yaitu: (a) Mayoritas wisatawan FIT Cina yang berkunjung ke Labuan Bajo dalam kurun waktu 2014-2020 adalah warga negara Cina yang berasal dari kota tier 1 (Beijing, Shanghai, Guangzhou, dan Shenzhen) dan emerging 1 (Chengdu, Chongqing) Cina; (b) Dari bulan kedatangan di tahun 2019, bulan September merupakan bulan kedatangan terbanyak wisatawan FIT Cina di Labuan Bajo. Selain bulan September, bulan November dan Juli juga menjadi waktu alternatif lain di mana wisatawan FIT Cina cukup banyak berkunjung ke Labuan Bajo; (c) Rerata pengeluaran wisatawan FIT Cina ketika melakukan perjalanan ke Labuan Bajo adalah 10.000 RMB/Orang. Apabila diamati lebih jauh, dari 137 data social listening, terdapat 22\% wisatawan yang mengeluarkan biaya minimal 15.000 RMB/Orang. Kelompok ini berasal dari kota kota Beijing, Shanghai, Guangzhou, Hangzhou, Chongqing, dan Shenzhen yang masih merupakan kota tier 1 dan emerging 1 Cina. Dengan melihat jumlah pengeluaran tersebut, maka wisatawan FIT Cina sudah sesuai dengan target market yang ditentukan oleh BPO LBF (Fatina, 2020); (d) Hotel pilihan wisatawan FIT Cina dengan minimal pengeluaran 15.000 RMB/Orang adalah Hotel Ayana (37\%), Hotel Sylvia (37\%), Hotel Sunset Hill (16\%), dan Ecco Tree Hotel (10\%); (e) Tipe perjalanan favorit wisatawan FIT Cina dengan pengeluaran 15.000 RMB/Orang adalah perjalanan bersama teman (50\%), pasangan (23\%), keluarga $(20 \%)$ dan solo traveler $(7 \%)$. Temuan ini tidak jauh berbeda apabila dilihat dari semua wisatawan FIT Cina tanpa melihat besaran jumlah pengeluaran; (f) Dalam hasil wawancara, unsur budaya dan interaksi wisatawan dengan masyarakat lokal menjadi salah satu kriteria mereka dalam mengukur kualitas pengalaman selama berkunjung ke destinasi. Beberapa unsur budaya yang dimaksud adalah kuliner lokal dan pengenalan keunikan budaya setempat; (g) Wisatawan FIT Cina memiliki perbedaan pilihan platform digital dalam mencari informasi seputar destinasi, melakukan pemesanan tiket dan akomodasi, hingga platform digital yang digunakan untuk membagikan pengalaman mereka selama berkunjung di destinasi tertentu; (h) Platform digital yang dipilih pada poin sebelumnya mayoritas merupakan platform yang aktif digunakan oleh mayoritas masyarakat Cina berusia 20-39 tahun yang juga menjadi mayoritas usia wisatawan FIT Cina (Dudarenok, 2020).

Wisatawan FIT Cina memiliki preferensi dalam melihat daya tarik utama Labuan Bajo. Menurut hasil social listening, daya tarik utama Labuan Bajo bagi wisatawan FIT Cina adalah Pink Beach yang terletak di kawasan Taman Nasional Komodo, Labuan Bajo. Fakta ini juga diperkuat dengan pernyataan Happy Komodo (2021) yang menyatakan bahwa wisatawan Cina sangat menyukai atraksi alam Labuan Bajo, seperti Pink Beach dan Pulau Padar. Selain daya tarik alam tersebut, hewan endemik komodo juga menjadi salah satu pendorong utama bagi wisatawan FIT Cina untuk pergi ke Labuan Bajo.

Kekuatan Pink Beach sebagai daya tarik utama Labuan Bajo diungkapkan oleh beberapa tulisan dalam platform Mafengwo di bawah ini:

"Ketika pertama kali melihat Pink Beach di platform Mafengwo, saya merasakan ketertarikan yang sangat mendalam dengan tempat itu.” (Akun Mafengwo 旭哥带你看世界, 2019) 
"Di Pulau Komodo, saya menemukan Pink Beach yang amat saya sukai." (Akun Mafengwo Sasa, 2019)

"Seorang teman mengirimkan saya sebuah foto yang dia percaya bahwa saya akan menyukainya. Foto itu adalah Pink Beach. Kesan pertama yang terlintas saat itu adalah Bahama, ternyata saya salah, tempat itu ternyata ada di Pulau Komodo dan tidak jauh dari Bali, sehingga saya tidak perlu mengurus visa. Saya memperoleh foto itu tanggal 4 September dan langsung membeli tiket penerbangan saat itu juga. Tiket penerbangan yang saya pilih adalah keberangkatan tanggal 17 September." (Akun Mafengwo 张大脸, 2019)

Selain Pink Beach, Komodo juga menjadi salah satu daya tarik dari pariwisata Labuan Bajo bagi wisatawan FIT Cina. Hal ini dapat terlihat pada pernyataan-pernyataan di bawah ini:

"Sekitar 23 tahun yang lalu, ayah saya pergi dinas ke luar negeri dengan membawa oleholeh berupa ensiklopedia jenis hewan dunia. Pada halaman 106, ada tulisan tangan yang isinya: Naga Komodo.... Hidup sejak jaman dinosaurus, termasuk hewan langka dan kuno... hanya ada di Indonesia. 'Baiklah, mari pergi ke sana' kataku pada ayah di bulan Maret." (Akun Mafengwo Explorer, 2019)

"Saya baru sadar bahwa perjalanan satu tahun lalu saya belum sempat menuliskan pengalaman perjalanan selama di Bali-Labuan Bajo. Oleh karena itu, tahun ini saya memutuskan untuk kembali ke Labuan Bajo demi melihat komodo dan ke Bali untuk bersenang-senang." (Akun Mafengwo Alisa, 2020)

Tidak hanya itu, kekuatan komodo sebagai salah satu daya tarik pariwisata Labuan Bajo adalah nama Pulau Komodo (科目多岛) yang lebih dikenal oleh masyarakat Cina jika dibandingkan dengan Labuan Bajo (拉布汉芭蕉). Fakta ini juga bisa dilihat pada jumlah temuan hasil tiap kata kunci Pulau Komodo dan Labuan Bajo di Baidu. Hasil pencarian kata kunci Pulau Komodo di Baidu pada tanggal 15 Juni 2021 adalah 2.260.000 buah/detik, sedangkan Labuan Bajo adalah 59 buah/detik (baidu.com). Kekuatan daya tarik Pink Beach dan hewan endemik komodo tidak hanya terlihat pada hasil social listening platform Mafengwo saja, tetapi juga pada platform digital Cina yang lain, yaitu RED. Dalam hasil pencarian dengan kata kunci Pulau Komodo (科目多岛), maka mayoritas hasil konten yang keluar terlihat menggunakan foto Pink Beach dan komodo. Selain Pink Beach dan komodo, paket wisata live on board juga menjadi hal yang paling menarik bagi wisatawan FIT Cina yang telah berkunjung ke Labuan Bajo. Fakta ini terlihat pada salah satu tulisan Mafengwo yang menekankan bahwa salah satu wisatawan FIT melakukan kunjungan kembali ke Labuan Bajo untuk kembali merasakan pengalaman live on board di Labuan Bajo:

"Setelah menyelesaikan ujian OW Mei tahun lalu, saya berkenalan dengan grup penyelam Guangzhou dan memutuskan untuk pergi ke Pulau Komodo demi merasakan live on board yang saya pikir akan sama saja dengan paket live on board di tempat lain. Akan tetapi, setelah datang ke sana, saya merasa bahwa live on board di Labuan Bajo tidaklah mudah. Oleh karena itu, tahun ini saya kembali ke Labuan Bajo untuk merasakan live on board dengan persiapan yang lebih lengka dan matang. " (Akun Mafengwo Mac, 2019)

Dari beberapa pemaparan di atas, dapat ditarik kesimpulan bahwa Pink Beach dan hewan endemik komodo dapat dijadikan sebagai pembeda (differentiation) Labuan Bajo dengan destinasi lain yang ada di Indonesia bahkan dunia. Dalam era digital, proses diferensiasi produk Labuan Bajo ini disebut sebagai brand clarification of character and codification dimana calon wisatawan FIT yang terkumpul dalam komunitas konsumen daring dapat mengklarifikasi kebenaran informasi mengenai keunikan dan janji (promise) produk pariwisata Labuan Bajo dengan bantuan teknologi internet.

Pembahasan subbab kali ini menggunakan bantuan model Segitiga Strategi-Taktik-Nilai yang disusun oleh Kotler et al. (2004) sebagai pedoman dalam analisis hasil temuan lapangan dengan teori yang digunakan. Dalam Segitiga Strategi-Taktik-Nilai, ada tiga hal yang perlu diperhatikan, yaitu: (a) 
Lingkup strategi; bertujuan untuk merebut mind share wisatawan FIT Cina dengan cara membentuk identitas brand Labuan Bajo (identity brand) yang disesuaikan dengan target pasar wisatawan FIT Cina. Proses yang dilakukan untuk mencapai tujuan tersebut adalah analisis SWOT berdasarkan hasil analisis internal dan eksternal Labuan Bajo. Hasil dari analisis SWOT ini nantinya akan memperlihatkan daya tarik utama apa yang dapat digunakan oleh Labuan Bajo untuk membangun identitas brand di sistem komunitas digital wisatawan FIT Cina; (b) Lingkup taktik; bertujuan untuk memperoleh market share wisatawan FIT Cina dengan mempertahankan integritas brand Labuan Bajo. Integritas brand yang dimaksud di sini adalah keunikan dan janji (promise) Labuan Bajo terhadap wisatawan FIT Cina. Di era digital, Kotler, et al. (2017) menyebutkan proses diferensiasi brand di sini dengan istilah brand clarification of character and codification. Kotler et al. (2017) menekankan bahwa di era digital, brand harus konsisten dalam memperkuat keunikan produknya sehingga dapat memperoleh pengakuan dari komunitas konsumen daring mengenai ketepatan janji yang ditawarkan oleh brand (promise). Selain itu, pada lingkup taktik, Kotler et al. (2004) juga menekankan pada pemanfaatan bauran pemasaran 4P yang di era digital berubah menjadi bauran pemasaran terhubung 4C (Kotler et al., 2017); (c) Lingkup nilai; bertujuan untuk memperoleh heart share wisatawan FIT Cina. Fokusnya adalah citra brand (image brand) sehingga di era digital saat ini, Kotler et al. (2017) menyatakan sangat penting bagi brand untuk memiliki sistem pelayanan yang melibatkan konsumen dalam proses penyelesaian masalah yang dihadapi konsumen. Proses penyelesaian masalah konsumen harus cepat dan responsif mengingat target pasar di era digital adalah konsumen yang terintegrasi dalam satu komunitas daring (collaborative customer care). Selain itu, Kotler et al. (2017) juga menekankan bahwa citra brand pada era digital akan dipengaruhi oleh tingkat engagement brand dengan komunitas konsumen daring yang terdapat dalam berbagai platform digital Cina.

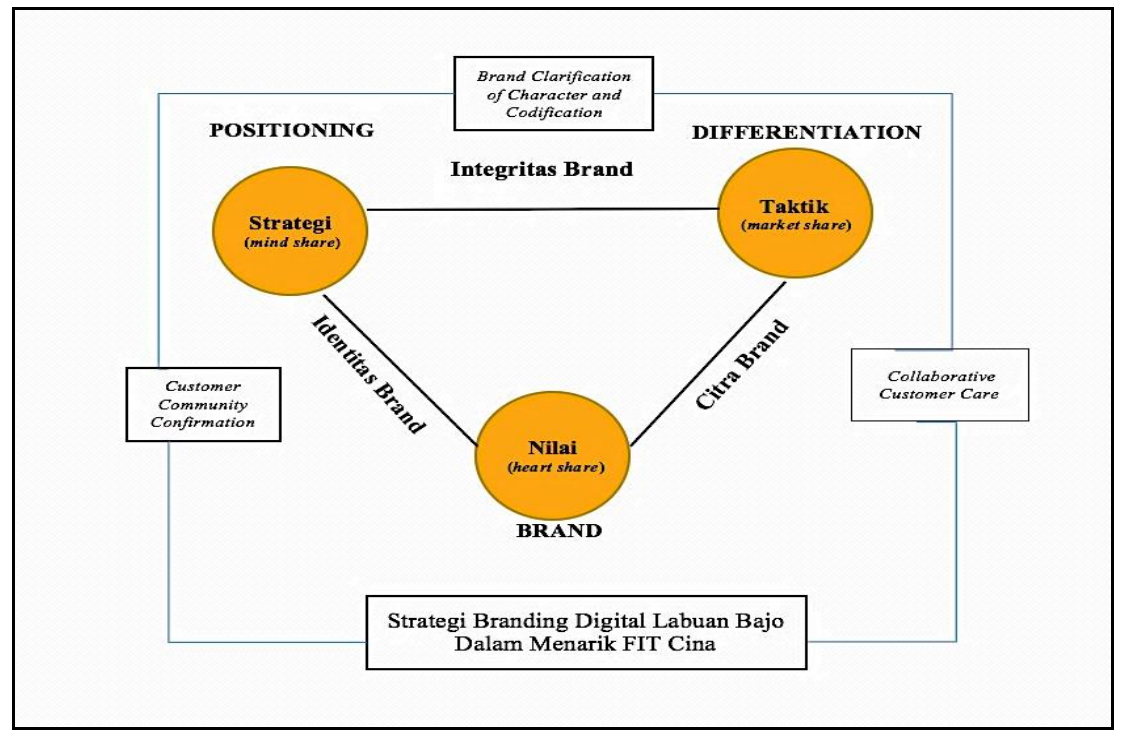

Sumber: Kotler et al. (2004); Suryawardani et al. (2021)

Gambar 1.

Analisis Branding Digital Labuan Bajo

Dari sisi layanan konsumen di era digital, dua akun Wonderful Indonesia (WI) yang mewakili Labuan Bajo dalam penyampaian branding destinasi di platform digital Cina, ternyata belum memiliki sistem pelayanan konsumen yang tergolong cepat dalam menanggapi konsumen. Hal ini terlihat ketika pada tanggal 30 Mei 2021 penelitian ini mencoba mengirimkan pertanyaan melalui akun WI di Sina 
Weibo dan WeChat, satu respon pun tidak diterima hingga tanggal 15 Juni 2021. Hasil ini tentu kurang sesuai dengan standar digital yang menuntut sistem layanan konsumen dapat merespon dan memberikan solusi pada konsumen dengan tingkat waktu kecepatan yang baik (fast response).

Tabel 1.

Identifikasi SWOT Branding Labuan Bajo dan Wisatawan FIT Cina

\begin{tabular}{cc}
\hline \multicolumn{1}{c}{ Strength } & Weakness \\
\hline Pink Beach, Pulau Padar, dan komodo dapat & Labuan Bajo belum memiliki sistem \\
$\begin{array}{l}\text { menjadi representasi brand pariwisata Labuan Bajo } \\
\text { bagi wisatawan FIT Cina }\end{array}$ & $\begin{array}{l}\text { layanan konsumen kolaboratif di komunitas } \\
\text { konsumen daring Cina }\end{array}$ \\
\hline
\end{tabular}

Aktivitas pariwisata yang ada dalam live on

Konten Labuan Bajo masih terbatas

board seperti snorkeling dan menyelam adalah dalam platform digital Cina

aktivitas favorit bagi wisatawan FIT Cina

Bahasa Mandarin belum

dimanfaatkan dalam promosi brand Labuan

Bajo

\begin{tabular}{cc}
\hline Opportunity & Threat \\
\hline $\begin{array}{c}\text { Potensi pasar wisatawan FIT Cina yang } \\
\text { sangat besar secara global, termasuk di Labuan Bajo }\end{array}$ & $\begin{array}{l}\text { Potensi hadirnya informasi Labuan } \\
\text { Bajo yang tidak bisa dipertanggungjawabkan } \\
\text { kebenarannya (hoax) di sistem digital Cina }\end{array}$ \\
\hline
\end{tabular}

Wisatawan FIT Cina yang sesuai dengan

Adanya kompetitor destinasi bahari target pasar Labuan Bajo adalah wisatawan Cina asal lain, seperti Bali dan Manado

Tier 1 dan emerging 1

Besarnya potensi key opinion leader (KOL)

Cina dalam pemasaran digital Cina

Adanya pandemi Covid-19 yang terjadi secara global

Banyaknya jenis platform digital Cina yang dapat dimanfaatkan sebagai tempat mempromosikan brand Labuan Bajo

Sumber : Data Diolah, 2021

Dengan mengacu pada identifikasi SWOT Tabel 4.1, maka strategi branding digital yang dapat diimplementasikan oleh Labuan Bajo dalam menarik wisatawan FIT Cina adalah: (a) Strategi Branding SO (Strength and Opportunity) Strategi ini menekankan pada kekuatan brand yang dimiliki oleh Labuan Bajo sebagai destinasi super prioritas untuk memanfaatkan peluang meningkatnya wisatawan FIT Cina sebagai segmentasi pasar yang dituju oleh Labuan Bajo. Strategi ini spesifik untuk memanfaatkan prinsip segmentasi dan penargetan pasar di pemasaran tradisional yang menjadi customer community confirmation di era digital seperti yang telah diungkapkan oleh Kotler et al. (2017). Strategi ini terdiri dari: (1) Strategi Branding SO-1, memanfaatkan Pink Beach, Pulau Padar, komodo, dan aktivitas yang terdapat dalam live on board untuk dijadikan sebagai representatif Labuan Bajo untuk wisatawan FIT Cina. Pemanfaatan sebagai repsentasi brand di sini bisa dalam bentuk logo, konten, dan tagline destinasi; (2) Strategi Branding SO-2, memanfaatkan kekuatan Pink Beach, Pulau Padar, komodo, dan aktivitas yang terdapat dalam live on board Labuan Bajo untuk mendekati komunitas konsumen daring atau platform digital yang sering digunakan di kota Tier 1 dan Emerging 1 Cina. Beberapa platform tersebut di antaranya: WeChat, RED, Sina Weibo, Duoyin /TikTok, Baidu, Mafengwo, dan Fliggy; (3) Strategi Branding SO-3, bekerja sama dengan key opinion leader (KOL) 
Cina untuk meningkatkan brand awareness dan engagement Labuan Bajo dalam sistem platform digital Cina.

(b) Strategi Branding WO (Weakness and Opportunity) Strategi ini bertujuan untuk mengatasi kekurangan brand Labuan Bajo sebagai destinasi super prioritas demi menghadapi peluang yang ada dalam segmentasi pasar wisatawan FIT Cina. Strategi Branding WO ini fokus pada citra brand (image brand) yang terdapat dalam Segitiga Strategi-Taktik-Nilai. Kotler et al. (2017) secara spesifik menekankan pada collaborative customer care. Strategi ini terdiri dari: (1) Strategi Branding WO-1, memastikan performa sistem kolaborasi layanan konsumen Labuan Bajo di platform digital Cina yang dipilih di Strategi SO sebelumnya. Memiliki sistem kolaborasi layanan konsumen yang bagus akan meningkatkan citra Labuan Bajo dalam komunitas konsumen daring Cina; (2) Strategi Branding WO2, penggunaan bahasa Mandarin dalam setiap konten informasi mengenai Labuan Bajo dalam platform digital Cina yang telah dipilih dalam strategi SO-2 sebelumnya.

(c) Strategi Branding ST (Strength and Threat) Strategi ini fokus pada penggunaan kekuatan brand Labuan Bajo sebagai destinasi untuk menghadapi ancaman yang berasal dari luar. Startegi Branding ST ini menekankan pada proses diferensiasi produk yang menekankan nilai brand clarification of character and codification (Kotler et al., 2017). Salah satu cara untuk memperoleh klarifikasi brand tersebut adalah konsistensi penyediaan informasi Labuan Bajo di platform digital Cina dalam setiap fase customer path 5A. Strategi ini terdiri dari: (1) Strategi Branding ST-1, memaksimalkan keunikan Pink Beach, Pulau Padar, komodo, dan aktivitas ive on board dalam setiap konten informasi destinasi Labuan Bajo di platform digital Cina yang dipilih. Hal ini dilakukan untuk meningkatkan daya saing dan keunikan Labuan Bajo agar bisa bersaing dengan destinasi kompetitor lainnya, seperti Bali dan Manado; (2) Strategi Branding ST-2, penggunaan bahasa Mandarin dalam setiap konten yang dibuat dan diunggah di platform digital Cina yang telah dipilih. Hal ini harus dilakukan demi memastikan komunitas konsumen daring memperoleh informasi lengkap dan dapat mengklarifikasi janji (promise) produk destinasi Labuan Bajo; (3) Strategi Branding ST-3, pemanfaatan representasi brand Labuan Bajo (Pink beach, Pulau Padar, komodo, dan live on board) untuk terus mengunggah konten di platform digital agar tetap mempertahankan engagement Labuan Bajo, khususnya selama era pandemi, sehingga komunitas daring Cina bisa selalu mengetahui informasi terbaru dan terakurat mengenai perkembangan destinasi Labuan Bajo.

(d) Strategi Branding WT (Weakness and Threat) Strategi WT adalah sebuah strategi untuk meminimalisasi kelemahan yang dimiliki oleh brand Labuan Bajo untuk menghadapi ancaman yang ada di Labuan Bajo. Strategi ini terdiri dari: (1) Strategi Branding WT-1, meningkatkan engagement brand Labuan Bajo dengan kepada komunitas konsumen daring Cina melalui program loyalitas konsumen dan pemberian voucher perjalanan gratis ke Labuan Bajo; (2) Strategi Branding WT-2, membuat buku panduan wisata Labuan Bajo dalam bahasa Mandarin dan mengunggah buku tersebut dalam platform digital Labuan Bajo di komunitas daring Cina.

\section{SIMPULAN DAN SARAN}

Berdasarkan hasil analisis data lapangan yang dilakukan, penelitian ini memiliki beberapa kesimpulan, yaitu Dilihat dari komponen 4A, terutama komponen atraksi, Labuan Bajo memiliki daya tarik alam dan budaya yang sangat berpotensi untuk ditetapkan sebagai destinasi super prioritas di Indonesia. Daya tarik utama Labuan Bajo bagi wisatawan FIT Cina adalah Pink Beach, Pulau Padar, hewan endemik komodo dan kegiatan live on board. Strategi branding digital Labuan Bajo dalam menarik wisatawan FIT antara lain: (1) Menerapkan tiga poin pemasaran digital yang berkaitan dengan proses strategi branding Labuan Bajo, yaitu: customer community confirmation, brand clarification of character and codification, dan collaborative customer care; (2) Menggunakan Pink 
Beach, Pulau Padar, komodo, dan aktivitas live on board sebagai representasi (icon) Labuan Bajo dalam branding digital; (3) Target pasar yang dituju oleh branding digital Labuan Bajo secara geografi adalah wisatawan FIT Cina yang berasal dari kota di tier 1 dan emerging 1 Cina; (4) Platform digital dipilih berdasarkan pertimbangan usia pengguna, yaitu usia 20-39 tahun dan kota tier 1 dan emerging 1 Cina. Berdasarkan pertimbangan tersebut, maka komunitas konsumen daring Cina, seperti platform WeChat, Sina Weibo, RED, Duoyin/Tiktok, Baidu, Mafengwo, dan Fliggy adalah platform-platform yang sesuai untuk dijadikan tempat dalam promosi Labuan Bajo secara digital (customer community confirmation); (5) Penggunaan bahasa Mandarin juga diperlukan dalam setiap konten Labuan Bajo supaya konsumen daring dapat melakukan klarifikasi brand dan memperoleh informasi yang akurat seputar perkembangan pariwisata di Labuan Bajo (brand clarification of character and codification); (6) Meningkatkan performa sistem kolaborasi layanan konsumen dan bekerja sama dengan key opinion leader (KOL) Cina untuk meningkatkan brand awareness dan engagement Labuan Bajo dalam sistem platform digital Cina (collaborative customer care).

Penelitian ini memiliki beberapa dua jenis saran, yaitu saran yang bersifat praktis dan saran akademis. Beberapa saran praktis yang dapat diimplementasikan oleh pihak destinasi Labuan Bajo, antara lain: (1) Memperkuat kualitas SDM Labuan Bajo dalam menghadapi industri pariwisata, khususnya dalam menyambut wisatawan FIT Cina. Proses peningkatan kualitas SDM ini dapat berupa pendampingan transfer keahlian dan teknologi kepada para pelaku pariwisata, peningkatan kualitas pendidikan di Kabupaten Manggarai Barat dengan penambahan sekolah (SD, SMP, SMA, dan Perguruan Tinggi) dan tenaga pendidikan berkualitas, serta membangun kerja sama dengan stakeholder untuk mempercepat proses pembangunan kualitas SDM Manggarai Barat; (2) Memperkuat kualitas produk kuliner lokal Labuan Bajo, khususnya dari segi standarisasi cleanliness, health, safety, environment (CHSE), kebersihan proses pengolahan hingga penyajian, serta diversivikasi produk kuliner yang sesuai dengan preferensi wisatawan FIT Cina; (3) Menciptakan produk budaya yang menarik supaya wisatawan FIT Cina juga dapat mengenal mengenai budaya masyarakat lokal; (4) Membentuk tim pemasaran destinasi yang khusus mengelola pasar wisatawan FIT Cina.

\section{REFERENSI}

Akun Mafengwo Alisa. (2020). 科莫多岛, 南纬八度的粉色沙滩 (serial online), 6 Oktober 2020. http://www.mafengwo.cn/u/13056624.html

Akun Mafengwo Explorer. (2019). 侏罗纪公园漂流记一一科莫多岛四日船宿游记 (serial online), $23 \mathrm{Mei}$ 2019.

Akun Mafengwo Mac. (2019). 潜水船宿一印尼科莫多- 巴厘岛 (serial online), 13 Agustus 2019. http://www.mafengwo.cn/i/16611264.html

Akun Mafengwo Sasa. (2019). 印度尼西亚的地狱和天堂@爪哇岛\&科莫多岛 (serial online), 23 November 2019. http://www.mafengwo.cn/i/17957971.html

Akun Mafengwo 张大脸. (2019). 巴厘岛+科莫多”粉红沙滩上留下的美好回忆〜 (serial online), 6 Januari 2019. http://www.mafengwo.cn/i/11564894.html

Akun Mafengwo 旭哥带你看世界. (2019). 即将关闭的”科莫多岛 (serial online), 12 Agustus 2019 . http://www.mafengwo.cn/u/85448436.html

Bandar Udara Komodo. (2019). Data Kedatangan dan Keberangkatan Wisatawan Mancanegara Tahun 2019.

BPO LBF. (2021). Final Report: NSPK Strategi Promosi Destinasi Premium.

Buletin BPIW Kementerian PUPR. (2020). Sinergitas Pengembangan Lima Destinasi Pariwisata Super Prioritas.

Direktur Pemasaran BPO LBF. (2020). Wawancara Destinasi Labuan Bajo [virtual interview].

Direktur Utama BPO LBF. (2021). Wawancara Destinasi Labuan Bajo [virtual interview].

Dudarenok, A. G. (2020). How to Win with Chinese Tourist. Chozan.

Evans, N. (2015). Strategic management for tourism, hospitality and events. Routledge. 
Fatina, S. (2020). Forum Floratama: Pengembangan Pariwisata Premium Berkelanjutan dan Ekonomi Kreatif di Flores, Alor, Lembata, dan Bima (Floratama) [PowerPoint Slides]. BPOLBF.

Happy Komodo. (2021). Wawancara Destinasi Labuan Bajo [virtual interview].

Keller, K., Parameswaran, A. M. G., \& Jacob, I. (2015). Strategic Brand Management: Building, Measuring, and Managing Brand Equity. Pearson India Education Service Pvt.Ltd.

Kodir, A., Tanjung, A., Astina, I. K., Afif Nurwan, M., Gatra Nusantara, A., \& Ahmad, R. (2020). The Dinamics of Access on Tourism Development in Labuan Bajo Indonesia. Geojournal of Tourism and Geosites, 29(1), 662-671.

Kotler, Philip, \& Gertner, D. (2004). Country as brand, product and beyond: a place marketing and brand management perspective. Destination Branding: Creating the Unique Destination Proposition, 2(2), 4056.

Kotler, Philip, Kartajaya, H., \& Young, S. D. (2004). Attracting investors: a marketing approach to finding funds for your business. John Wiley \& Sons.

Kotler, Phillip, Kartajaya, H., \& Setiawan, I. (2017). Marketing 4.0: Moving from Traditional to Digital. John Wiley \& Sons. Inc.

Pike, S. (2008). Destination marketing: An integrated marketing communication approach. Routledge.

Rudiyanto, Roseven, Hutagalung, S., Ciptosari, F., \& Siswoyo, S. (2021). Survey Kepuasan Pengunjung (Passengers Exit Survey) 2020 di Kabupaten Manggarai Barat. Sustour.

Son, J. (2015). Consumers in an online brand community: uses and gratifications, social capital, and brand loyalty. IOWA State University.

Suryawardani, I. G. A. O., Wiranatha, A. S., Satriawan, I. K., Pujaastawa, I. B. G., Kencana, E. N., \& Tika, I. W. (2021). The Role of Branding in Increasing Revisit to Agritourism at Jatiluwih in Bali. SOCA Jurnal Sosial Ekonomi Pertanian, 15(2).1-20.

Suwena, I. K., Widyatmaja, I. G. N., \& Atmaja, M. J. (2010). Pengetahuan Dasar Ilmu Pariwisata. Udayana University Press.

Vincent. (2021). Wawancara Destinasi Labuan Bajo [virtual interview]. 